This item was submitted to Loughborough's Research Repository by the author.

Items in Figshare are protected by copyright, with all rights reserved, unless otherwise indicated.

\title{
A resource-advantage perspective on the orchestration of ambidexterity
}

PLEASE CITE THE PUBLISHED VERSION

http://dx.doi.org/10.1080/02642069.2014.942655

\section{PUBLISHER}

(c) Taylor \& Francis

\section{VERSION}

AM (Accepted Manuscript)

\section{PUBLISHER STATEMENT}

This work is made available according to the conditions of the Creative Commons Attribution-NonCommercialNoDerivatives 4.0 International (CC BY-NC-ND 4.0) licence. Full details of this licence are available at: https://creativecommons.org/licenses/by-nc-nd/4.0/

\section{LICENCE}

CC BY-NC-ND 4.0

\section{REPOSITORY RECORD}

Hodgkinson, lan R., M.N. Ravishankar, and Michelle Aitken-Fischer. 2019. "A Resource-advantage Perspective on the Orchestration of Ambidexterity”. figshare. https://hdl.handle.net/2134/17320. 


\section{A Resource-Advantage Perspective on the Orchestration of Ambidexterity}

Ian R. Hodgkinson (corresponding author) ${ }^{1}$

School of Business and Economics, Loughborough University, Loughborough, United Kingdom.

\section{M.N. Ravishankar}

School of Business and Economics, Loughborough University, Loughborough, United Kingdom.

\section{Michelle Aitken-Fischer}

School of Business and Economics, Loughborough University, Loughborough, United Kingdom.

${ }^{1}$ Loughborough University, School of Business and Economics, Loughborough, Leicestershire LE11 3TU, United Kingdom. Tel: +44 (0)1509 223865. Fax: +44 (0)1509 223962. E-mail: I.R.Hodgkinson@lboro.ac.uk. 


\title{
A Resource-Advantage Perspective on the Orchestration of Ambidexterity
}

\begin{abstract}
Strategic resources are key inputs to strategy that can form the basis of superior service performance, yet there is scarce research on the strategic resources used by managers to realise ambidexterity: the simultaneous pursuit of alignment and adaptability. In this paper, we draw on a qualitative case study of a leading European airline and examine the resource bundles used by managers in their orchestration of ambidexterity. Adopting a resource-advantage perspective, the study illustrates elements of human, organisational, and informational capital that are mobilised by managers in their incorporation of alignment-oriented and adaptability-oriented activities. By moving beyond a linear association between strategic resources and ambidextrous organisations, we argue that managers' orchestration of ambidexterity is central to how service organisations manage their strategic resources and enhance competitiveness. Overall, we highlight the micro managerial-level as an important point of observation to extend current thinking on the 'how' of ambidexterity in service organisations.
\end{abstract}

Keywords: ambidexterity; strategic capital; case study; resource-advantage theory 


\section{Introduction}

Successful firms require the ability to simultaneously a) move quickly toward new opportunities, adjust to volatile markets, and avoid complacency (adaptability) and b) possess a clear sense of how activities should be coordinated and streamlined in line with strategic plans in order to deliver value (alignment) (Birkinshaw \& Gibson, 2004). The study of how both adaptability and alignment can be achieved simultaneously, rather than being seen as mutually exclusive, is addressed within the literature on ambidexterity but is primarily understood at a macro level (Turner \& Lee-Kelley, 2012). In other words, prior research on ambidexterity has typically been positioned at the macro-level of the firm or the business unit, while empirical studies that examine the construct at a more micro managerial-level are scarce (Nosella, Cantarello, \& Filippini, 2012). There is limited theorisation and empirical evidence within the literature on how alignment and adaptability are achieved at the lower level of operations. This paper takes a small, but important step towards addressing this gap.

Senior management occupy decision-making roles that require the behavioural capacity to articulate strategic intent, set strategic direction, plan, and command (Floyd \& Lane, 2000). They are known to ratify initiatives and provide direction based on a set of assumptions about conditions in the business environment (Floyd \& Lane, 2000). Strategy, in this sense is seen to be deliberate, reflecting the specific intention of senior managers. This prescribed intent guides resource allocations (Mintzberg, Ahlstrand, \& Lampel, 1998), sets general directions and defines emerging market opportunities, subsequently providing an orientation that, on account of its clarity, can be pursued with consistency over time (Boisot, 1995). To avoid confusion and misinterpretation, some senior managers may in fact find it necessary to underplay ambidexterity, relying instead on clearly defined, one-dimensional strategic plans. It is then often left to middle managers to mediate between divergent inputs, situational demands, and the existing strategy during implementation (Floyd \& Lane, 2000). 
However, despite these clearly crucial tasks undertaken by middle managers, the largely macro-level focus of extant ambidexterity research has meant that most of the emphasis has been on the activities of senior managers and top management teams. In general, less is known about the impact of middle managers, and in particular about how they orchestrate ambidexterity at the operational level. The aim of this paper, therefore, is to explore the orchestration of ambidexterity by middle managers. Here, the phrase 'orchestration of ambidexterity by middle managers' refers to the incorporation of both alignment-based as well as adaptability-based activities by middle managers when delivering broadly defined strategic plans. Studying this orchestration clearly has the potential to offer a deeper understanding of ambidexterity at the micro-level than is currently understood using macrolevel themes (Turner, Swart, \& Maylor, 2012).

In exploring how middle managers orchestrate ambidexterity, this paper draws on the Resource-Advantage (R-A) theory and the notion of 'strategic capital'. Given that ambidexterity is inextricably linked to organisational resources (Jansen, Simsek, \& Cao, 2012), the constructs of R-A theory can be particularly helpful in identifying the resource requirements necessary for middle-managerial ambidextrous actions. This represents an advancement of ambidexterity research which has yet to build theory that explains how the specific resource attributes of the organisational context can shape ambidexterity among individual middle managers. Our findings, based on a qualitative case-study of a leading European airline suggest that though ambidexterity may be conceived of as an organisational approach to strategic management, it is middle management that enact highly ambidextrous actions in the implementation of senior management directed strategic plans. We also argue that underlying the broad overarching strategic goals of an organisation are a sequence of ambidextrous activities at the middle management level. Further, the resource endowments of the organisation's strategic capital base enable ambidexterity to occur at this level. 
We structure our arguments as follows. First, we review the literature on ambidexterity, middle-managers, the R-A theory and the concept of strategic capital. Second, we explain our methodology and introduce our case. Third, we present the findings of our study, focusing on middle managers' ambidextrous actions and on the enabling elements of the strategic capital base. We conclude with a discussion of our contributions and suggest directions for future research.

\section{Ambidexterity}

Researchers and practitioners are increasingly using the notion of ambidexterity to describe how managers are able to simultaneously pursue courses of action along two different dimensions or directions, during the implementation of strategy (Rothaermel \& Alexandre, 2009; Simsek, Heavey, Veiga, \& Souder, 2009; Raisch \& Birkinshaw, 2008; Tushman \& O’Reilly, 1996). Duncan (1976) first coined the term 'ambidexterity', introducing the idea of dual structures. The concept of structural separation between different types of activities has been explored at length in the literature (Gupta, Smith, \& Shalley, 2006; O’Reilly \& Tushman, 2004; Tushman \& O’Reilly, 1996; McDonough \& Leifer, 1983). However, we do not view ambidexterity as a structural separation of alignment-oriented and adaptabilityoriented activities, but rather as a complementary process triggered by managerial thinking and action (Birkinshaw \& Gibson, 2004).

More specifically, ambidexterity achieves alignment of activities towards pre-defined goals while also adapting effectively to changing environmental demands (O’Reilly, Harreld, \& Tushman, 2009; Atuahene-Gima, 2005; Gibson \& Birkinshaw, 2004; Adler, Goldoftas, \& Levine, 1999). The simple idea behind the value of ambidexterity is that managers, to various degrees, always contend with conflicting objectives (for instance, investment in current versus future projects, efficiency versus flexibility, differentiation versus low-cost 
production, incremental innovation versus radical innovation); so there are always trade-offs to be made (Gibson \& Birkinshaw, 2004). However, research on ambidexterity has begun to shift its focus from such trade-offs (either/or) to paradoxical (both/and) thinking. The contextual stream of ambidexterity research suggests that, when provided with a favourable context, managers are able to organise their working time so as to integrate both alignmentand adaptability-oriented activities in the course of their daily tasks. According to Gibson and Birkinshaw (2004), although trade-offs can never entirely be eliminated, the most successful organisations reconcile them to a large degree through their ambidextrous activities, and in so doing enhance their long-term competitiveness. More recently, Heracleous and Wirtz (2010) focusing exclusively on the services sector, have argued that ambidextrous thinking and action are central to the achievement of competitive advantage in the long term.

\section{Middle managers and ambidexterity}

Because many organisations develop habitual ways of interpreting events, which are often top down, they can easily miss the significance of new knowledge necessary for the implementation of appropriate change (i.e. adaptability). Interpreting such new knowledge has typically been viewed as the responsibility of senior managers, leaving the rest of the organisation to implement appropriate actions (Beck \& Plowman, 2009); yet this neglects the fundamental role of middle managers who, by their proximity to both strategic and front-line managers, contribute to the dynamic process of organisational interpretation.

Limited extant ambidexterity literature has considered the role of middle managers (e.g. Taylor \& Helfat, 2009) despite the fact that such individuals are:

'...close to day-to-day operations, customers and frontline employees - closer than senior managers are - so they know better than anyone where the problems are. But they're also far enough away from frontline work that they can see the big picture, 
which allows them to see new possibilities, both for solving problems and for encouraging growth’ (Huy, 2001, p. 73).

Middle managers are seen as 'a level of management in an organisation or business consisting of executives or senior supervisory staff in charge of the detailed running of an organisation or business and reporting to top management' (Collins Dictionary, 2009). Middle managers are boundary spanners, able to connect actors with different job responsibilities in an organisation, within or across units, through their activities (Taylor \& Helfat, 2009). Their ability to facilitate information flow and coordination between groups is consistent with the perspective that ambidexterity is embedded in the specific actions of individuals (Gibson \& Birkinshaw, 2004). Though researchers have identified the value of middle managers to 'manage' contradictory requirements in order to achieve long term success (Napier, Mathiassen, \& Robey, 2011; Huy, 2002), most normative models of strategy tend to accord middle management a supporting role at best (Shrivastava, 1986); however, middle managers connect an organisation's strategic and operational levels and are undervalued lynchpins in the strategy process (Balogun \& Johnson, 2004). Importantly, to be ambidextrous, organisations have to reconcile internal tensions and conflicting demands in their task environment (Raisch \& Birkinshaw, 2008); middle managers are fundamental to this. More specifically, middle managers champion, facilitate, synthesise, implement and communicate information between the operating and senior levels of management (Floyd \& Lane, 2000). Their strategic role enables them to present alternatives to top management, categorise issues, sell issues to top management, blend strategic and hands-on information, nourish adaptability, share information, guide adaptation, facilitate learning, revise and adjust, motivate and inspire (Floyd \& Lane, 2000). Middle managers, thus, have a number of responsibilities. This level of management

'...must maintain a degree of technical competence and a detailed understanding of the organisation's capabilities. To interact with top management, they must also 
understand the organisation's goals and competitive strategy, as well as the political context in which these are developed. The complexity of information and number of potential interactions, therefore, are greater for middle managers...' (Floyd \& Lane, 2000, p. 164).

\section{Middle managers, ambidexterity, R-A theory and strategic capital}

Organisational factors such as formal and informal structural mechanisms, strong corporate cultures and appropriate managerial characteristics have been offered as possible solutions for the various kinds of tensions that exist at the firm, team, and top management level (see Wang \& Rafiq, 2012; Andriopoulas \& Lewis, 2010; Smith, Binns, \& Tushman, 2010; Jansen, George, Van den Bosch, \& Volberda, 2008). Yet, the role of resources and capabilities has been largely ignored. We would therefore argue that it is important to examine how ambidexterity really emerges from the context by looking at internal resources and capabilities, which provide the micro-mechanisms for middle managers to resolve tensions (Nosella et al., 2012).

In thinking about how middle managers approach ambidexterity, and in consideration of their strategic role and behaviours, the R-A theory and the concept of strategic capital provide a useful analytical apparatus. The theory adopts a resource-based perspective of the firm, whereby firms are theorised to be combiners of heterogeneous, imperfectly mobile resources. Because many of the resources of firms within an industry are significantly heterogeneous (therefore, asymmetrically distributed among competitors) and relatively immobile (not readily available in the factor markets), the R-A theory suggests that through the deployment of available tangible and intangible resources (i.e. strategic capital) that produce increased value, an organisation will achieve superior performance relative to rivals (Hunt 2000). Strategic capital reflects various forms of human (e.g. employee skills, learning, 
commitment and training), informational (e.g. knowledge, understanding of markets, customers, etc.), relational (e.g. relationships, alliances and cooperative agreements) and organisational (e.g. culture, firm resources and capabilities) capital. Elements of strategic capital have been linked to increased value and the generation of competitive advantage in service organisations (Carvajal \& Nogales, 2013; Hodgkinson \& Hughes, 2012; Lu \& Yang, 2010). Since competitors attempt to neutralise and/or leapfrog the advantaged firm through acquisition, imitation, substitution, or major innovation, the R-A theory is inherently dynamic: it is a never-ending process of change, '...the process of R-A competition will not only allocate resources in an efficient manner, but also there will be both proactive and reactive innovations developed that will contribute to further increases in efficiency and effectiveness' (Hunt \& Derozier, 2004, p. 14). The R-A theory is thus useful as a means to understand the mechanisms for alignment and adaptability at the micro-level.

Under the R-A theory, senior management is accorded the role of recognising, understanding, creating, selecting, implementing and modifying strategy (Hunt \& Derozier, 2004); but it does not specifically address the role middle managers may play in these processes. The deployment of strategic capital begins with senior management directing the allocation of resources in pursuit of, or to reinforce, a particular strategic position (Floyd \& Lane, 2000). Once this commitment is made, it is middle managers who coordinate the pool of resources as required to implement the chosen strategy (Wooldridge \& Floyd, 1990). For instance, Bartlett and Ghoshal (1993) identified middle managers as helping to ensure the distribution of knowledge-based resources throughout the organisation; while, Wooldridge, Schmid, and Floyd (2008) suggest that middle managers as a group, are likely to serve as important catalysts for exploiting existing firm capabilities and for exploring the development of new ones. 
In summary, a review of the extant literature suggests that ambidextrous organisations demonstrate their ability to effectively manage emerging opportunities and threats. But this requires a superior ability to leverage existing strategic resources and to promote organisational routines that may help adapt in uncertain environments (Eisenhardt \& Martin, 2000). Indeed, organisations displaying high levels of ambidexterity have been found to leverage greater levels of strategic resources compared with those showing low levels of ambidexterity (Kouropalatis, Hughes, \& Morgan, 2012). Clearly, the resources endowed upon an organisation and the capability to effectively exploit them influences the level of flexibility organisations may exercise in uncertain environments. Yet a coherent understanding of the resources needed to enable ambidexterity and how middle managers deploy such resources to orchestrate ambidexterity in practice is lacking. In the subsequent empirical sections of the paper, we explore these issues in greater detail through an in-depth case study.

\section{Research methods}

In the spirit of Starbuck’s (2010, p. 1397) recent observation about how crucial insights can be developed 'by investigating carefully selected instances', we build our arguments through a qualitative case study of a leading European airline. This approach is also consistent with a growing number of single-case approaches in organisational research (e.g. Kauppila, 2010; O'Reilly, Harreld, \& Tushman, 2009).

\section{Research setting}

'Traditionally, the European airline industry has been dominated by state-owned operators, the so-called flag carriers, and it is only in the last 20 years that the concept 
of privatisation, initiated in the UK by the sale of British Airways, begun to have any impact on the industry' (Kangis \& O’Reilly, 2003, p. 105).

In considering strategies in a dynamic marketplace, Kangis and O’Reilly (2003) identify the deregulation of air travel in Europe as the catalyst for new players to enter the market with aggressive competitive mind-sets, forcing the once protected incumbents to restructure for survival, which in turn has created a dynamic and hyper-competitive, rather than a static, operating environment.

In this study, we focus on AIRCOM (a pseudonym), a well-known European airline with a distinguished history and reputation. AIRCOM is a global aviation company, which operates one of the world's leading European airlines. It offers passenger services to about 200 global destinations in more than 60 countries. AIRCOM employs more than 80,000 employees from 100 nationalities and is also a major partner in a well-known airline alliance arrangement. Structurally, AIRCOM is organised into a handful of strategic business units (SBUs), through which it delivers a wide-range of passenger and cargo services.

\section{Data collection}

We used multiple sources of qualitative data including field notes, minutes of internal communications between middle managers and senior management, AIRCOM's corporate website and articles in the business press about the strategies implemented by AIRCOM's different SBUs. One of the main sources of data came from semi-structured interviews with 16 middle managers in five SBUs. Access to middle managers at AIRCOM was negotiated by one of the authors, who for many years, worked as a consultant in the aviation sector. All the interviews were digitally recorded and transcribed. In the main, the interview questions focused on whether and how middle managers aligned rigidly to strategic plans as opposed to adapting to emerging situations, and the drivers and enablers of such approaches. An 
illustrative list of open-ended questions directed the flow of conversation with the managers and also provided a flexible setting for exploring a wider-range of related issues (Bryman, 2001). Informants included middle managers in a number of areas such as sales, pricing, HR, training and development, operations, business development and brand management.

The management consulting experience (within the aviation sector) of one of the authors helped us better understand the socially constructed worlds of the middle managers at AIRCOM and generate data that provided rich insights into their views and perceptions. Mindful of social desirability effects that have been highlighted as a potential limitation of interview-based methods (Kvale, 1996), we also took care to ask similar questions in different ways, probe informants' explanations and justifications in-depth, and triangulate apparent contradictions and inconsistencies.

\section{Data analysis}

We analysed the qualitative data generated in our fieldwork by travelling back and forth between the data and emerging structure of theoretical arguments (e.g. Pratt, Rockmann, \& Kaufmann, 2006). Consistent with Pratt et al. (2006) we utilised three major steps of analysis: Step 1: Creating provisional categories and first-order codes. This step involved using open coding to identify informants’ quotes about their aligning and adapting approaches and then drawing on common statements to form provisional categories and first order codes.

Step 2: Integrating first-order codes and creating theoretical categories. This stage of analysis allowed us to create theoretical categories by comparing the empirical data across middle managers in different SBUs.

Step 3: Delimiting theory by aggregating theoretical dimensions. Once theoretical categories had been generated, we looked for dimensions underlying these categories in an attempt to understand how different categories fitted together in a coherent picture. 
Figure 1 summarises the processes that we followed. It also shows our first-order categories, theoretical categories, and aggregate theoretical dimension. Specifically, it shows how the aggregate theoretical dimension of operational ambidexterity was arrived at through our analysis of the empirical data.

Insert Figure 1 about here

\section{Alignment and adaptation at AIRCOM}

Middle managers at AIRCOM operate in a highly dynamic and competitive environment. The empirical data showed that they engaged in a range of activities, some of which were clearly aligned to pre-determined strategic plans, while others deviated from original plans and could be viewed as nimble operational adaptations to changing demands.

Strategic planning and an emphasis on strategy content were clearly evident in the projects that middle managers were entrusted with. Many informants offered illustrative examples of strategic and systematic planning in the delivery of projects. An integration manager elaborated on the planning activities underpinning a mobile-check in service project:

'In the pre-study we had to first verify whether the mobile devices of our passengers were capable of displaying the mobile boarding pass because nothing is worse than offering a highly innovative product and everyone says "well yes, I want a mobile boarding pass. Please send it to my phone”, and then say, "I haven’t received it, it doesn’t work, what are you doing AIRCOM?” So we had various test cases, ones we tested on customers at the gate. We said "while you have a boarding pass, do you want to participate in our test?” and we sent them the same boarding pass via mobile technology and asked them to board the aircraft because we wanted to see if it displayed correctly and if it passed through the boarding gate, which worked perfectly. 
Prior to that we did various test cases in our lab with various devices and ordered an external design of the mobile boarding pass.'

At the same time, middle managers were quick to adapt in the process of achieving the overall objectives of their project. A middle manager responsible for implementing the mobile boarding pass project explained:

'At the outset of the project we said we're going to deliver it with multi messaging services. So we had to go around asking customers what mobile phone they had, which model etc., to see if we could get a perfect display resolution of the barcode on that specific device. To answer these questions, customers had to open the back of their device, take out the battery and see underneath to find out which model they had. But this is obviously a hassle. So we had to quickly reconsider the technology we proposed to use. The technology in the mobile device area is growing so fast, so rapidly, that your goals over the long-term don't change but you have to adapt how you're going to solve problems to achieve them.'

Middle managers also noted that the global crisis of 2008 rendered many of AIRCOM's prior strategic plans completely unworkable. As a result they had to quickly adapt to the emerging realities of the business environment. They therefore viewed short-term adaptability as a priority, viewing long-term strategic planning and alignment as having limited relevance in their highly unstable and uncertain operating environment. As a global sales manager put it: 'We had to adapt quickly after the crisis. With our usual approach, our department was just not delivering fast enough in a rapidly changing environment'. AIRCOM middle managers reasoned that their adaptation to strategy implementation was best done 'by moving step by step'. They argued that it was important to recognise where the environment is rather than predicting where it will be. In other words, they seemed to place a premium on rapid adaptation rather than over-rely on carefully constructed strategic plans (see Schoemaker, 2002). Particularly in the aftermath of the global recession, middle managers 
increasingly felt that intended organisation-level strategies had to be adapted with 'great freedom and flexibility'. Indeed, a number of technology sourcing and buying decisions at AIRCOM had to be re-evaluated at the middle management level and managers had to make sure that 'the existing technology went further' in the service of customers.

Overall, in line with theoretical formulations of strategy implementation (e.g. Quinn, 1980), middle managers appeared to experiment and learn from a series of partial commitments rather than through global formulations of total strategies. Some informants described their guiding ethos for implementation of strategy as 'let's try it and if it doesn't work, okay, we have tried it, if it does work, perfect'. In short, middle managers at AIRCOM appeared to display a behavioural capacity to facilitate both alignment and adaptability simultaneously. Next, we address the salient organisational resources which enabled and constrained middle managers' orchestration of both alignment and adaptability, i.e. the resources which anchored the ambidextrous activities of middle managers.

\section{Ambidextrous activities and strategic capital}

It was evident from our interviews with middle managers that the mobilisation of the various elements of strategic capital was central to their activities of alignment and adaptability.

\section{Champions}

Champions are described as individuals who sponsor, provide impetus to, and are perceived to 'take-on' a strategy (Howell \& Shea, 2001). The championing behaviour of AIRCOM middle managers helped create adherence to strategy (see Royer, 2003), and was also key in bringing innovation attempts to fruition (see Howell \& Shea, 2001). We found that middle managers evaluated the long-term implications of experiments and championed the cause of the most promising ones among them. An airport manager explained how he not only 
strongly advocated for the innovative mobile boarding pass project, but also clearly addressed the related fears of airport-based employees:

'In 2008, we introduced a 2D barcode based mobile boarding pass system. I think it's great that we use new technology and lead by example and I think that is really important. But airport staff feared that they might lose their job. I took great pains to explain that was not our goal that we were actually trying to save jobs here though we might not create new jobs. We put in a lot of effort to save the jobs here to make the staff feel safe. It's not us that they have to compete with; it's the other carriers.'

Middle managers argued that they enjoyed a much closer relationship with front-line workers than senior executives did and were therefore more attuned to employees' needs (see Huy, 2002). They felt strongly that if they did not play an active championing role, alignment to shared goals could become blurred and there would be an increased resistance to adaptability. Middle managerial commitment to strategy was clearly a key characteristic of successful championing at AIRCOM, as it built support for the relevant strategy, provided impetus to its development and assisted in limiting resistance to change (see Wooldridge \& Floyd, 1990). A training and development manager charged with improving efficiencies through a blended learning project elaborated on the championing duties of middle managers:

'You have to understand the way the front-line employees work in terms of their day to day operations. If you're asking them to take on additional responsibilities that they're not getting paid for, responsibilities which will take them away from all the other things that they're doing, with very little reward for them personally, you have to convince them first of the positive sides and what you are going to do for them that will help them take on this additional work.'

Extant literature suggests that the impetus for autonomous initiatives stems not from top managers but from middle managers who recognise and champion ideas as new strategic initiatives (Wooldridge et al., 2008), but the contribution of championing to ambidexterity 
and what this means in practice has not been considered. It was evident from our interviews that the championing activities of middle managers emanated from a 'divergent' mind-set (Floyd \& Wooldridge, 1992) and that these activities were central to ambidexterity. A pricing manager illustrated how in operationalizing a broad strategy for cluster-based pricing he actually challenged senior-management thinking and championed crucial adaptations to the strategy:

'Our strategy, as envisioned by the vice-president was to stop putting different prices on each route. Instead we were supposed to design clusters and put various routes into them. Each cluster was supposed to be priced differently. I was involved in this project every day, so I saw that having different unique clusters didn’t make sense. So we actually bunched clusters together, since I felt that it’s good enough if we can have one condition set for two clusters. I was the one who was making the decision and I said, "that's the way we have to do it". I was able to convince the senior management.’

\section{Implementation support and effectiveness}

Menon, Bharadwaj, Adidam, and Edison (1999) concluded from interviews with managers that strategies often failed due to a lack of necessary resources. At AIRCOM, the availability of support resources for implementation was a key element in the implementation of strategy and played a critical role in enabling middle managers to facilitate ambidexterity. As a middle manager explained:

'We tried to create some kind of area-wide management support structure, where employees can have one spot, one special point of contact where they can discuss problems from an administrative point. In other words, when their station manager won’t let them or won't give them the resources to do what they need to do, then who are they going to turn to? If they can't turn to the person who's saying no, they need to 
turn to another structure. So that's been part of the strategy - looking not just at how to implement, but also providing a support structure post-implementation in order to maintain an effective strategy. Otherwise employees will say these managers come in, give us something new and then after that, it's sink or swim, and I think that you can ease it for them if you can show them that you're putting in a support structure that will assist them.’

Once the commitment was made by senior management regarding the allocation of resources, middle managers were expected to put into place the necessary structure, people, and systems needed for implementing the strategy, which involved the quest for additional resources. Middle managers felt that the hardest part of the implementation process was 'gaining access to necessary resources', with a recurring problem being that resources weren't available to support the implementation of strategy. It became evident from the perceptions of middle managers that implementation support and implementation effectiveness are intertwined by necessity since, as a middle manager put it: 'for changes to be implemented there must be dedicated training for people to cope with their new activities along the way'. Effective implementation is seen as a critical capability and organisational element of strategic capital (Hunt, 2000) that enables management to implement and modify strategies as necessary (Seggie \& Griffith, 2007). Middle managers explained how they were able to implement adaptations effectively by redeploying resources and pursuing new ideas. An illustrative example from a HR manager:

'We had decided to implement web-based training; however the existing software did not allow us to capture new changes which was essential for training purposes and that's why I came up with the idea of looking for a different tool that makes it easier to actually capture current processes. We had meetings with five different software companies and they showed us their tools, but in the end it was also a matter of money. So I selected the one which I had the best feeling with, and that was also 
reasonable, and this is now the third year we've been working with it. Though we had a certain plan of how it should be used to implement the training project, we have had to adjust all the time because despite what the software was capable of, we found that not all functions were compatible with our data. I mean things happen along the way which requires you to reorganise and move resources around.'

Managers also linked effective adaptability to clear communication strategies: 'We had good communication always. We always said why we did it and what the changes are and had systems in place to understand how they felt about it because you have to take them with you'. Middle managers pointed out that they implemented change 'very openly' and 'listened to input and steering' from front-line employees; the middle managers also viewed personal awareness, understanding, acceptance and commitment to change among front-line employees as a necessity (see Quinn, 1980). An inability to effectively implement strategy and failure to successfully change direction through the communication of strategic changes were seen as important barriers to the orchestration of ambidexterity. A middle manager elaborated on a failed implementation: 'The change hadn't dripped down through the communication system that AIRCOM had down to individuals. We didn't translate the change of strategy into "What do I need to do differently to what I did yesterday?" for frontline employees’.

\section{Organisational learning}

Organisational learning is a critical informational and knowledge-based element of strategic capital, which relates to the firm's products, processes, customers, competitors and resources (Griffith, Yalcinkaya, \& Calantone, 2010; Hunt, 2000). The process of organisational learning was triggered by the knowledge which flowed through middle managers. These managers were uniquely positioned to evaluate the value of information to the airline since 
they had more knowledge of the strategic situation (relative to front-line employees), as well as more familiarity with operational matters (relative to senior managers) (see Floyd \& Lane, 2000). We also found that middle managers actively sought to gather new information, which helped them learn quickly and adapt to trends and changes in the market:

'We did a lot of information gathering using multiple tools, processes and systems in order to gain intelligence on our customer segments to be in a position to respond to that intelligence. This also involved sending questionnaires to the 300 employees I was responsible for to better understand their job function and the role's they had, what they liked and what didn't like about the role'

Middle managers also organised and utilised social events strategically for information gathering and learning purposes. Such social events were viewed as very important occasions, especially since AIRCOM operated in a very dynamic and competitive business environment:

'Because briefing is a huge topic in a business that changes every day...we do things like go bowling or have pizza nights and then talk about some of the topics that need to be talked about. It's networking and though it's something tiny in itself, it'll only cost $\$ 100$ to get pizza for everyone, but the outcome of that networking and that learning is huge in comparison'.

Organisations learn from operating in their respective marketplaces whilst competing and through this can become aware of the means to provide value to customers beyond their competitors (Hunt, 2000). Middle managers argued that their learning capabilities help explain AIRCOM's competitiveness and strategic flexibility, pointing out that excellent learning capabilities were at the root of their quick responsiveness to customers and to external environmental changes (see Griffith et al., 2010). As the middle manager for business development explained: 
'During the recession we realised that our very strong dependency on corporate business was harming us...I started my own initiative to identify crisis resistant businesses by analysing the environment and identifying opportunities for development. Because of this work we developed a full focus on the leisure market and segments within that market. In 6 months we had 835 new contracts'

Middle managers encouraged their teams to constantly question 'who are we?', 'who is our customer?', 'what is our product?' and 'how is it different to our competitors?' As Sadler (2007) notes, great companies do not fall into the same trap twice; meaningful stories were passed between actors in the organisation from which managers drew valuable lessons 'about what the customer wants from the service'. In short, middle managers' strengths in leveraging the organisational knowledge resources helped them to implement strategy in agile ways, allowing them to change direction quickly. A middle manager responsible for training and development highlighted the significance of knowledge resources, particularly for adaptability:

'In order to learn about, and respond faster to, changes in the internal and external environment we moved away from the traditional training strategy of all come together and exchange experiences to web-based virtual training. This meant that upto-date knowledge was available to employees wherever and whenever they wanted it, allowing us to adapt to changes with speed and efficiency’

A middle manager for product marketing reiterated how learning capabilities proved fundamental for exploring new opportunities, which required a change in behaviour:

'The call centre in AIRCOM is very time driven. A call centre agent has 90 seconds to finish a call to the customer. Their PC screen displays a ticking clock and if all necessary questions are not asked in that time period it's not good for their score card. However, introducing a product like AIRCOM private jet required a complete shift in thinking, where time doesn't matter. Productivity is not the most important thing, to develop a relationship between the customer and the sales agent, that's the most 
important thing. I helped them to unlearn old priorities to realise the importance of this relationship.’

\section{Discussion}

The empirical data presented in the findings section demonstrates how middle managers' at AIRCOM incorporated activities of both alignment and adaptability in their operationalization of the organisation's strategic plans. While there is clear evidence of the 'what' of ambidexterity within the literature-its enactment at the organisational level has been shown to be beneficial (Turner \& Lee-Kelley, 2012)-our data suggests that the middle managerial level is an important point of observation from which to study the 'how' of ambidexterity. One could argue that the ways in which middle managers at AIRCOM worked with strategic directives and plans is what they were expected to do anyway. However, what our data also indicates is that even when they work with a finite set of organisational resources, the mindfulness and agility displayed by middle managers in navigating through activities of alignment and adaptability crucially determines the extent to which specific projects run smoothly. The mobile boarding pass example cited in the findings section is a case in point. This also suggests that there are bound to be significant variations across organisations in the ways in which middle managers orchestrate ambidexterity. While our case highlights some successful examples, it is reasonable to expect middle managerial ambidextrous activities to end in unsatisfactory outcomes when they fail to take into account the emerging realities of the immediate context and the business environment.

The findings also illustrate that disagreement or questioning of official strategy by middle managers resulted in greater championing behaviour (Wooldridge et al., 2008). Such divergent thinking clearly helped middle managers to better respond to and adapt general strategic directives. The presence of champions at the middle managerial level can thus be 
seen as a resource, which enabled AIRCOM to effectively balance alignment and adaptability in the process of strategic decision making. It is also evident from the data that the influence exerted by the 'championing' resources were closely linked to the strengths of the larger organisation in mobilising complementary resources in areas such as information technology and employee training. Overall, the championing actions of our informants emphasises the significance of the middle manager role in delivering ambidexterity and also challenges assertions that middle managers are merely exploitative, unlike leaders who are deemed to be capable of ambidextrous actions (Dover \& Dierk, 2010).

At the organisational-level, ambidexterity's continued implementation and successful leveraging requires diverse and timely resource inputs (Jansen et al., 2012). Though it may be unsurprising to find that high ambidextrous organisations, relative to low ambidextrous organisations, are endowed with greater levels of implementation support and implementation effectiveness (see Kouropalatis et al., 2012), our findings suggest that these strategic resources are also identifiable in individual middle managers. Menon et al. (1999) imply an association between resource commitment (strategy support) and strategy implementation success, which is evident in the findings where accessibility (or lack thereof) to support resources appeared to both facilitate and impede middle managers' orchestration of ambidexterity. Although middle managers could not directly align the resource structure of AIRCOM to support their operational needs, they played a proactive role in managing activities closely linked to implementation effectiveness. We would argue that it is this capability to effectively deploy and coordinate available resources for emerging needs that distinguishes high and low individual managerial ambidexterity. Though implementation effectiveness may be described in abstract terms as an organisational resource, the role played by the middle management in creating this resource through their ambidextrous activities cannot be underestimated. 


\section{Navigating between alignment and adaptability}

The explication of the relationship between alignment and adaptability is a classic debate of strategic management. Mellahi and Sminia (2009) have argued persuasively that the two approaches have to acknowledge and build on each other, which forms the central premise of ambidexterity. Alignment is rooted in the content approach to strategic management which emphasises systematic analysis and integrative planning (Wiltbank, Dew, Read, \& Saravathy, 2006). This systematic planning has as its primary goal the improving of the ability to define and structure planning problems by effective interaction with the environment, but also by acknowledging conditions of uncertainty (Mintzberg et al., 1998). This perspective of planning was clearly evident in the projects that middle managers at AIRCOM were entrusted with. However, comprehensive planning can blind managers to important changes in the competitive environment (see Wiltbank et al., 2006) as experienced by AIRCOM middle managers during the global recession. Hence, there is the simultaneous need for adaptability which is especially important when an environment is highly competitive and dynamic such as the European airline industry (see Mintzberg \& Waters, 1985). Adaptability is rooted in the processual approach to strategic management and was evidenced by managers learning what to do next by minimising the use of predictive rationality, and instead experimenting and moving quickly to capture new opportunities (see Mosakowski, 1997). In AIRCOM’s case, such adaptability was illustrated by the middle-management led expansion into the leisure market business, which was viewed as relatively 'crisis-resistant'. As a brand manager observed, 'you can have a plan and a goal and you think that it is so easy to get there, but then along the way you have to adjust all the time because you're facing so many problems'. Consistent with Gibson and Birkinshaw (2004), the findings present alignment and adaptability as constituting separate, but interrelated, non-substitutable elements of the 
strategy implementation process. Further, the findings also demonstrate how alignmentoriented and adaptability-oriented activities are complementary in the operationalization of strategy, and are often enacted by middle managerial thinking and action.

\section{A typology of ambidexterity scenarios in service organisations}

By considering the strategic management process in one airline at a particular stage in its history, we have attempted to explore how middle managers perceive the strategy process and how alignment and adaptability can be simultaneously developed and maintained at the operational level. Mintzberg and Waters (1985) state that managing requires the need to direct in order to realise intentions while simultaneously responding to an unfolding pattern of action. It is therefore not only important for middle management to produce outcomes that are well aligned with organisational objectives, but also to successfully adapt to new information that emerges within and after strategy implementation (Tiwana, 2008). Though this in itself has been established by extant strategy literature, this study has sought to apply this perspective to the airline industry, and has demonstrated that an airline's strategic capital base, when mobilised by middle managers can facilitate ambidexterity.

Drawing on our qualitative data we next build a typology of four possible ambidexterity scenarios unfolding in organisations (see Figure 2). We begin with the AIRCOM case scenario (top-left quadrant in Figure 2) but in acknowledging variations in both the degree of ambidextrous intent (on the part of senior managers) and operational ambidexterity (on the part of middle managers) in different organisational contexts, we outline a further three illustrative examples of alternative scenarios that require investigation. First, middle managers could act as the lynchpins of ambidextrous activities in the absence of clear ambidextrous intent on the part of senior managers. In this scenario, middle managers take on a proactively entrepreneurial role, effectively mobilising the strategic capital base and 
both aligning and adapting in accordance with the unfolding business environment. Secondly, in some organisations middle managers' orchestration of ambidexterity could be fully supported by senior-management driven strategic plans that demonstrate a clear commitment to flexibility and adaptation. In this ideal case, middle managers may find that there is already a strong strategic capital base, which they can take advantage of during the strategy implementation process. Access to this strategic capital base helps middle managers take a pragmatic and flexible approach to the activities they are expected to undertake. A third type of scenario unfolds when senior managers emphasise ambidextrous activities in their strategic plans and documents, but middle managers' implementation activities have a onedimensional and dogmatic orientation on account of a weak and inadequate strategic capital base. In this situation, senior managers need to focus their energies more on building a robust strategic capital base. In other words, mere articulation of ambidextrous intent at the senior management level may not result in ambidextrous activities at the operational levels. Finally, in certain cases we might expect to see an over-emphasis on clear strategic plans by senior managers and an equally rigid adherence at the middle management level to these plans. While such a scenario might work to the advantage of organisations in stable and predictable business environments, it is almost certain to lead to drift and a loss of competitive advantage in hyper-competitive settings that require agility and nimbleness in managerial decisionmaking.

Insert Figure 2 about here

\section{Operational ambidexterity}

The empirical material presented in this paper underpins one specific view of ambidexterity. The ambidexterity orchestrated by middle managers at AIRCOM largely involved managerial 
'activities' of alignment and adaptability at the operational level. We might therefore inductively theorise ambidexterity at the activity level as 'operational ambidexterity'. This view needs to be carefully contrasted with what we might refer to as the 'outcomes' school of ambidexterity. In this second perspective, ambidexterity is typically understood as the accomplishment of two hitherto opposing and contradictory strategic outcomes such as cost leadership/differentiation and sustainability/high profits. For example, Singapore Airlines’ is known to successfully achieve two seemingly contrasting outcomes at the same time; the airline provides customers with a high-quality service and dominates the business-travel segment, and yet, is the industry's most cost-effective operator. As Heracleous and Wirtz (2010, p.145) observe, the airline has combined 'the supposedly incompatible strategies of differentiation-which it pursues through service excellence and continuous innovation-and cost-leadership’. A few other empirical studies have also examined ambidexterity as an outcome. Adler et al. (1999) explore how firms can simultaneously achieve superior efficiency and superior flexibility. In a similar vein, Sadler (2007) proposes that 'great' companies diversify their supply bases, products, customers, and geographic markets while simultaneously maximising their returns on existing assets. In the literature, scholars tend to conflate the 'activities' and 'outcomes' notions of ambidexterity, leading to much conceptual confusion. In our research, we have primarily examined middle managers' orchestration of operational ambidexterity. In other words, the contribution of this paper is largely to the 'activity' school of ambidexterity. Drawing on this important distinction, we would urge scholars to bridge the two schools of ambidexterity by examining how ambidexterity at the operational level impacts organisations’ quest for ambidextrous outcomes.

\section{Contributions to research}


We began our article by discussing the importance of ambidexterity for organisations in highly dynamic and competitive environments and identified that the role played by middle managers is yet to be comprehensively explored. Our research contributes to a better understanding of strategy implementation in service-based firms by identifying how middle managers approach ambidexterity, in the context of a service organisation's strategic capital base. We identified dimensions of strategic capital that when mobilised by middle managers, favour ambidexterity. These include championing, strategy implementation support, strategy implementation effectiveness, and organisational learning, which are defined as strategic under the R-A theory prescriptions of heterogeneity, immobility, and value (Hunt and Morgan, 1995). These strategic resources have yet to be considered collectively in a study of ambidexterity and highlight a need for further research with respect to the resource attributes necessary for the orchestration of ambidexterity.

When applied to the study of middle managers' orchestration of ambidexterity, R-A theory suggests that their capacity for ambidexterity is purely a function of the availability of tangible and intangible resources that comprise the organisation's strategic capital base. However, this view accords a somewhat secondary status to the agency of middle managers. Drawing on our findings, we would suggest that in many cases it is in fact middle managers that play a fundamental role in creating, developing and mobilising the strategic capital and the strength of this capital base ultimately limits their ability for ambidextrous activity. In this sense, the relationship governing strategic capital, middle managers and ambidexterity can be seen as circular rather than linear. Therefore, R-A theory may be better understood in concert with the intent and actions of middle managers.

Put differently, moving beyond a linear association between strategic resources and ambidextrous organisations (see Kouropalatis et al., 2012), this study argues that middle managers' orchestration of ambidexterity may be central to how organisations manage their 
strategic resources and enhance competitiveness. It also offers new insights for practitioners in service industries. In particular, the paper can help service organisations to get a better sense of the vital resource mechanisms by which middle managers can orchestrate ambidexterity effectively.

\section{Concluding remarks}

In the current tough economic climate, service organisations have emphasised the importance of tenacious and imaginative approaches to strategic thinking and decision-making. Here, we examine ambidexterity as one such approach. Through our study, we firstly believe that practitioners will benefit from an increased awareness about the resource underpinnings required to facilitate ambidexterity. Secondly, our study suggests the crucial ways in which organisational nimbleness and agility could be fostered through middle managers, particularly in contexts of resource constraints. Lastly, we have identified internal drivers, namely strategic capital dimensions, of ambidextrous interventions and their consequences for strategy implementation to help broaden middle managers’ understanding.

Though our study focuses on a specific instance, the transferable nature of the findings generated will help middle managers across a range of service industries and sectors learn about the processes of adopting ambidextrous techniques for improved organisational performance. Quite often, decision-makers within organisations are required to choose between two opposing strategic options, each of which reflects a specific ideological or/and economic stance. A complete commitment to one course of action almost certainly results in over-allocation of resources and time to that particular strategy, and then, organisations are in no position to effectively switch to an alternative strategy when the strategic path is unfavourable or when pressures from the environment demand a change in strategy. In this 
context, our study will contribute towards helping organisational decision-makers avoid the traps of dogmatic decision-making.

We acknowledge several limitations of this study. First, it is based on a single case and therefore caution must be exercised in generalising to other settings. However, this paper can aid in 'naturalistic generalisation' (e.g. Pratt et al., 2006) whereby scholars and practitioners might recognise patterns based on experiences with similar 'cases', of course without making any statistical inferences (Stake, 1995). Second, we focused entirely on internal middle managers opinions and did not seek the opinions of wider stakeholders involved in the strategy implementation process, which might indeed provide a different perspective on operational ambidexterity. Third, a part of the explanation for the consistent responses of middle managers across SBUs could lie in the conforming values and norms of the national culture of AIRCOM, for example, risk aversion may influence the bias towards alignment or adaptability; however, we did not consider the broader dimension of national cultures in our study.

In conclusion, this research has identified the role played by middle managers in facilitating the development of operational ambidexterity, and provides a useful analytical framework to help us understand how the meta-capabilities of alignment and adaptability simultaneously flourish in organisations at the activity level. Future research should seek to further examine the capacity of middle managers to facilitate operational ambidexterity in a range of service industry contexts.

\section{References}

Adler, P.S., Goldoftas, B., \& Levine, D.I. (1999). Flexibility versus efficiency? A case study of model changeovers in the Toyota production system. Organization Science, 10(1), 43-68. 
Andriopoulos, C., \& Lewis, M.W. (2010). Managing innovation paradoxes: Ambidexterity lessons from leading product design companies. Long Range Planning 43(1), 104-22.

Atuahene-Gima, K. (2005). Resolving the capability-rigidity paradox in new product innovation. Journal of Marketing, 29, 61-83.

Balogun, J., \& Johnson, G. (2004). Organizational restructuring and middle manager sensemaking. The Academy of Management Journal, 47(4), 523-549.

Bartlett, C. A., \& Ghoshal, S. (1993). Beyond the m-form: toward a managerial theory of the firm. Strategic Management Journal, 14(S2), 23-46.

Beck, T.E., \& Plowman, D.A. (2009).Experiencing rare and unusual events richly: The role of middle managers in animating and guiding organizational interpretation. Organization Science, 20(5), 909-924.

Birkinshaw, J., \& Gibson, C.B. (2004). Building ambidexterity into an organization. MIT Sloan Management Review, 45(4), 46-55.

Boisot, M.H. (1995). Information space: a framework for learning in organizations, institutions and culture. London: Routledge.

Bryman, A. (2004). Social research methods. Oxford: University Press.

Carvajal, S.A., \& Nogales, A.F. (2013). How to support the management of intangibles. The Service Industries Journal, (in press).

Collins. (2009). Collins English Dictionary. Harper Collins: London.

Duncan, R.B. (1976). The ambidextrous organization: designing dual structures for innovation. In R.H. Kilmann, L.R. Pondy, \& D.P. Slevin (Eds.), The Management of Organization: Strategy and Implementation Volume I. (pp. 167-188). New York: Elsevier.

Dover, P.A., \& Dierk, U. (2010). The ambidextrous organization: integrating managers, entrepreneurs and leaders. Journal of Business Strategy, 31(5), 49-58. 
Eisenhardt, K.M., \& Martin, J.A. (2000). Dynamic capabilities: what are they? Strategic Management Journal, 21(10/11), 1105-21.

Floyd, S.W., \& Lane, P.J. (2000).Strategizing throughout the organization: managing role conflict in strategic renewal. The Academy of Management Review, 25(1), 154-177.

Gibson, C.B., \& Birkinshaw, J. (2004). The antecedents, consequences, and mediating role of organizational ambidexterity. Academy of Management Journal, 47(2), 209-226.

Griffith, D.A., Yalcinkaya, G., \& Calantone, R.J. (2010). Do marketing capabilities consistently mediate effects of firm intangible capital on performance across institutional environments? Journal of World Business, 45(3), 217-227.

Gupta, A.K., Smith, K.G., \& Shalley, C.E. (2006). The interplay between exploration and exploitation. Academy of Management Journal, 49(4), 693-706.

Heracleous, L., \& Wirtz, J. (2010). Singapore airlines’ balancing act. Harvard Business Review, (July/August), 145-149.

Hodgkinson, I.R., \& Hughes, P. (2012). The performance implications of strategic capital for public leisure providers. The Service Industries Journal, 32(8), 1375-1391.

Howell, J.M., \& Shea, C.M. (2001). Individual differences, environmental scanning, innovation framing, and champion behavior: Key predictors of project performance. Journal of Product Innovation Management, 18(1), 15-27.

Hunt, S.D. (2000). A general theory of competition. Thousand Oaks, CA: Sage.

Hunt, S.D., \& Derozier, C. (2004). The normative imperatives of business and marketing strategy: grounding strategy in resource-advantage theory. Journal of Business \& Industrial Marketing, 19(1), 5 - 22

Hunt, S.D., \& Morgan, R.M. (1995). The comparative advantage theory of competition. Journal of Marketing, 59(April), 1-15.

Huy, Q.N. (2001). In praise of middle managers. Harvard Business Review, 79(8), $72-79$ 
Huy, Q.N. (2002). Emotional balancing of organizational continuity and radical change: the contribution of middle managers. Administrative Science Quarterly, 47(1), 31-69.

Jansen, J.J.P, George, G., Van den Bosch, F.A.J., \& Volberda, H.W. (2008) Senior team attributes and organizational ambidexterity: the moderating role of transformational leadership. Journal of Management Studies, 45(5), 982-1007.

Jansen, J.J.P., Simsek, Z., \& Cao, Q. (2012). Ambidexterity and performance in multiunit contexts: cross-level moderating effects of structural and resource attributes. Strategic Management Journal, (in press).

Kangis, P., \& O’Reilly, M.D. (2003). Strategies in a dynamic marketplace: A case study in the airline industry. Journal of Business Research, 56(2), 105-11.

Kangis, P., \& O’Reilly, M.D. (1998). Strategic responses to competitive pressures: European air transport. Strategic Change, 7(3), pp. 167-182.

Kauppila, O.P. (2010). Creating ambidexterity by integrating and balancing structurally separate interorganizational partnerships. Strategic Organization, 8(4), 283-312.

Kouropalatis, Y., Hughes, P., \& Morgan, R.E. (2012).Pursuing “flexible commitment” as strategic ambidexterity: an empirical justification in high technology firms. European Journal of Marketing, 46(10), 1389-1417.

Kvale, S. (1996). InterViews. An introduction to qualitative research interviewing. London: Sage.

Lu, C.S., \& Yang, C.C. (2010). Logistics service capabilities and firm performance of international distribution center operators. The Service Industries Journal, 30(2), 281298.

McDonough, E., \& Leifer, R. (1983). Using simultaneous structures to cope with uncertainty. Academy of Management Journal, 26(4), 727-735. 
Mellahi, K., \& Sminia, H. (2009). Guest editors’ introduction: the frontiers of strategic management research. International Journal of Management Reviews, 11(1), 1-7.

Menon, A., Bharadwaj, S.G., Adidam, P.T., \& Edison, S.W. (1999). Antecedents and consequences of marketing strategy making: a model and a test. Journal of Marketing, 63(2), 18-40.

Mintzberg, H., Ahlstrand, B., \& Lampel, J. (1998) Strategy safari. The Free Press: New York Mintzberg, H., \& Waters, J.A. (1985). Of strategies, deliberate and emergent. Strategic Management Journal, 6(3), 257-272.

Mosakowski, E. (1997). Strategy making under causal ambiguity: conceptual issues and empirical evidence. Organization Science, 8(4), 414-442.

Napier, N.P., Mathiassen, L., \& Robey, D. (2011). Building contextual ambidexterity in a software company to improve firm-level coordination. European Journal of Information Systems, 20(6), 674-690.

Nosella, A., Cantarello, S., \& Filippini, R. (2012). The intellectual structure of organizational ambidexterity: A bibliographic investigation into the state of the art. Strategic Organization, 10(4), 450-465.

O’Reilly, C.A., Harreld, J.B., \& Tushman, M.L. (2009). Organizational ambidexterity: IBM and emerging business opportunities. California Management Review, 51(4), 75-99.

O’Reilly, C.A., \& Tushman, M.L. (2004). The ambidextrous organization. Harvard Business Review, 82(April), 74-82.

Pratt, M.G., Rockmann, K.W., \& Kaufmann, J.B. (2006). Constructing professional identity: the role of work and identity learning cycles in the customization of identity among medical residents. Academy of Management Journal, 49(2), 235-262.

Quinn, J.B. (1980). Strategies for change: logical incrementalism. Illinois: Irwin. 
Raisch, S., \& Birkinshaw, J. (2008). Organizational ambidexterity: antecedents, outcomes, and moderators. Journal of Management, 34(3), 375-409.

Royer, I. (2003). Why bad projects are so hard to kill. Harvard Business Review, 81(February), 48-56.

Rothaermel, F.T., \& Alexandre, M.T. (2009). Ambidexterity in technology sourcing: the moderating role of absorptive capacity. Organization Science, 20(4), 759-780.

Sadler, C. (2007). The four principles of enduring success. Harvard Business Review, 85(7/8), 62-72.

Seggie, S.H., \& Griffith, D.A. (2007). The resource matching foundations of competitive advantage. International Marketing Review, 23(3), 262-275.

Schoemaker, P.J.H. (2002). Profiting from uncertainty: Strategies for succeeding no matter what the future brings. New York: Free Press.

Shrivastava, P. (1986). Is strategic management ideological? Journal of Management, 12(3), 363-377.

Simsek, Z. (2009). Organisational ambidexterity: towards a multilevel understanding. Journal of Management Studies, 46(4), 597-624.

Simsek, Z., Heavey, C., Veiga, J.F., \& Souder, D. (2009). A typology for aligning organisational ambidexterity’s conceptualisations, antecedents, and outcomes. Journal of Management Studies, 46(5), 864-894.

Sminia, H. (2009). Process research in strategy formation: theory, methodology and relevance. International Journal of Management Reviews, 11(1), 97-125.

Smith, W.K., Binns, A., \& Tushman, M.L. (2010). Complex business models: Managing strategic paradoxes simultaneously. Long Range Planning, 43(2/3), 448-61.

Stake, R. (1995). The art of case study research. Thousand Oaks, CA: Sage. 
Starbuck, W.H. (2010). What makes a paper influential and frequently cited? Journal of Management Studies, 47(7), 1394-1404.

Taylor, A., \& Helfat, C.E. (2009). Organizational linkages for surviving technological change: complementary assets, middle management, and ambidexterity. Organization Science, 20(4), 718-739.

Tiwana, A. (2008). Do bridging ties complement strong ties? An empirical examination of alliance ambidexterity. Strategic Management Journal, 29(3), 251-272.

Turner, N., \& Lee-Kelley, L. (2012). Unpacking the theory on ambidexterity: An illustrative case on the managerial architectures, mechanisms and dynamics. Management Learning, 44(2), 179-196.

Turner, N., Swart, J., \& Maylor, H. (2012). Mechanisms for managing ambidexterity: a review and research agenda. International Journal of Management Reviews, 15(3), 317-332.

Tushman, M.L., \& O’Reilly, C.A. (1996). Ambidextrous organizations: Managing evolutionary and revolutionary change. California Management Review, 38(4), 8-30.

Wang, C.L., \& Rafiq, M. (2012). Ambidextrous organizational culture, contextual ambidexterity and new product innovation: A comparative study of UK and Chinese high-tech firms. British Journal of Management, (in press).

Wiltbank, R., Dew, N., Read, S., \& Saravathy, S.D. (2006). What to do next? The case for non-predictive strategy. Strategic Management Journal, 27(10), 981-998.

Wooldridge, B., \& Floyd, S.W. (1990). The strategy process, middle management involvement, and organizational performance. Strategic Management Journal, 11(3), 231-241. 
Wooldridge, B., Schmid, T., \& Floyd, S.W. (2008). The middle management perspective on strategy process: contributions, synthesis, and future research. Journal of Management, 34(6), 1190-1221. 
Figure 1. Overview of data structure

First-Order Codes

Statements about "the plan” (e.g. consultation, analysis, meetings, KPIs, etc.)

Statements about "how we did it" (e.g. "an analysis of the tools, processes, and systems”)

Statements about "problems faced" (e.g. "not timely enough", "It needed more flexibility”)
Theoretical Categories

Aggregate Theoretical Dimension
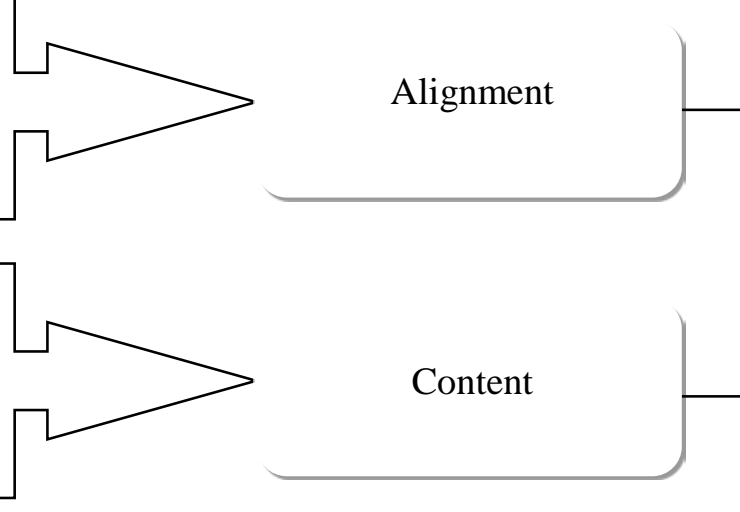
we adapted" (e.g. "by moving step by step", "did it very openly")

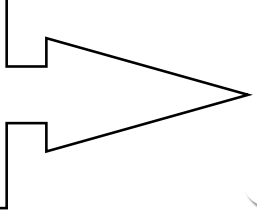

Process

Operational Ambidexterity 


\section{Figure 2. Four possible ambidexterity scenarios}

Middle managers' orchestration of ambidextrous activities

\begin{tabular}{|c|c|c|}
\hline & $\begin{array}{l}\text { Business thrives on the } \\
\text { ability of middle managers } \\
\text { to adapt to emerging } \\
\text { situations despite centrally } \\
\text { mandated rigid strategic } \\
\text { plans. }\end{array}$ & $\begin{array}{l}\text { Strategic plans emphasise } \\
\text { flexibility and adaptation. A strong } \\
\text { strategic capital base enables } \\
\text { middle managers to change } \\
\text { direction when required. }\end{array}$ \\
\hline \multirow{3}{*}{ Low } & $\begin{array}{l}\text { Strategy implementation is } \\
\text { aligned to rigid strategic } \\
\text { plans. This can lead to } \\
\text { drift and loss of } \\
\text { competitiveness over time. }\end{array}$ & $\begin{array}{l}\text { Strategy emphasises } \\
\text { flexibility and adaptation. } \\
\text { But implementation can } \\
\text { suffer from a weak strategic } \\
\text { capital base. }\end{array}$ \\
\hline & & \\
\hline & AmDIaexI & i senior managers’ \\
\hline
\end{tabular}
strategic plans 